\title{
KUALITAS DAGING ITIK FERMENTASI YANG DIRENDAM MENGGUNAKAN L. plantarum DENGAN LEVEL YANG BERBEDA DAN DISIMPAN PADA SUHU RENDAH
}

\section{Rahmawati Hadju}

\section{Fakultas Peternakan Universitas Sam Ratulangi Manado, 95115}

\begin{abstract}
ABSTRAK
Penelitian ini bertujuan untuk mempelajari pengaruh lama perendaman pada itik fermentasi terhadap kualitas $(\mathrm{pH}$, kadar air, kadar asam asetat dan total bakteri asam laktat) daging itik yang direndam menggunakan kultur L. plantarum dan disimpan pada suhu rendah. L. plantarum digunakan pada level yang berbeda-beda. Penelitian ini menggunakan rancangan acak lengkap. Data yang berbeda nyata dilanjutkan dengan analisa HSD. Hasil yang diperoleh menunjukkan bahwa perlakuan berbeda nyata $(\mathrm{P}<0,01)$ terhadap $\mathrm{pH}$ dan jumlah bakteri asam laktat dari itik fermentasi, tetapi tidak berbeda nyata $(\mathrm{P}>0,05)$ terhadap kadar air dan kadar asam asetat dari itik fermentasi . Dari penelitian ini disimpulkan bahwa perendaman pada level $15 \%$ L. plantarum dan disimpan selama 16 hari masih mempunyai kualitas yang baik.
\end{abstract}

Kata kunci : Fermentasi, daging itik, pH, air, asam asetat, asam laktat.

\author{
ABSTRACT \\ THE CHEMICAL QUALITIES OF \\ FERMENTED DUCK IMMERSED WITH
}

DIFFERENT LEVELS OF L. plantarum AND STORED UNDER LOW TEMPERATURE. The objective of this research was study the effect of soaking time on chemical $(\mathrm{pH}$, water content, acetic acid content and total lactic acid bacteria) of duck meat fermentation using L. plantarum. Ducks was done by soaking duck meat in culture L.plantarum and stroraged at cooling temperature. Soaking was done with different level of $L$. plantarum. This experiment was arranged in a completely randomized design consisted of five levels of L. plantarum. Data were analyzed by variance analysis. Significantly difference treatment effects on variable measures were tested using honestly significant difference (HSD). The result showed that treatments had significantly difference $(\mathrm{P}<0,01)$ on $\mathrm{pH}$ and total lactic acid bacteria of duck meat fermentation, but did not affect significant $(\mathrm{P}>0,05)$ on water content and acetic acid content of duck meat fermentation. Therefore, it can be concluded that soaking at $15 \%$ level of L. plantarum and storage at cooling temperature can conserve duck meat until 16 days and ducks fermentation were still constant.

Keywords: Fermentation, duck meat, pH, water, acetic acid, lactic acid. 


\section{PENDAHULUAN}

Tingkat selera masyarakat terhadap daging itik adalah tingkat yang paling rendah dibandingkan dengan daging unggas lainnya. Berbeda dengan Indonesia masyarakat Filipina dan Thailand, memiliki selera yang sama terhadap daging itik maupun daging ayam, hal ini mungkin dalam pengolahan daging itik di kedua Negara tersebut dilakukan beberapa teknik sehingga daging itik memiliki tempat yang sama dengan daging ayam.

Adapun beberapa factor yang menyebabkan daging itik kurang disukai masyarakat di Indonesia, selain daging itik alot dan amis juga disebabkan selama ini variasi pengolahan daging itik yang bisa mengundang selera konsumen sangat terbatas (Murtijo, 1999). Akibatnya harga daging itik relative murah dibanding harga daging ayam. Harga seekor itik dewasa hanya 10 kali harga sebutir telur itik. Unutk menghilangkan bau amis pada daging itik perlu banyak bumbu yang digunakan, tetapi tidak semua orang menyukai pengolahan daging itik menggunakan rempah-rempah yang begitu banyak. Selain itu daging itik jika dimasak menghasilkan minyak yang sangat banyak sehingga tidak semua orang menyukai hal seperti ini.
Dalam penjualan daging itik jelas bahwa pengolahan sangat penting, jika keterampilan mengolah dimiliki oleh peternak hasil usaha akan lebih meningkat dan masalah pemasyarakatan daging itik akan terpecahkan. Dalam mengolah kelunakan daging setelah dimasak perlu diperhatikan karena umumnya kelunakan daging merupakan ukuran praktis bagi setiap konsumen, menyusul rasa dan aroma hasil pengolahan.

Di Sulawesi Utara cara tradisional yang sering dilakukan dalam melunakkan daging adalah dengan memanfaatkan bambu dalam memasak makanan atau daging yang keras, dalam bambu banyak terdapat mikroba yang bersifat proteolitik yang dapat melunakkan daging sehingga daging yang keras jika dimasak didalam bambu akan menjadi lunak dan empuk.

Saguer atau cuka aren merupakan hasil fermentasi dari nira aren yang dapat digunakan untuk menghilangkan bau amis pada daging dan dapat digunakan sebagai bahan pengawet (Bachman, 1991). Tingkat fermentasi yang dilakukan dapat mempengaruhi kadar asam asetat yang dihasilkan.

\section{Lactobacillus}

plantarum merupakan bakteri asam laktat yang dapat memperbaiki warna daging dan juga dapat digunakan sebagai bahan pengawet pada daging (Surono,2000). Hasil penelitian sebelumnya diketahui bahwa daging itik 
yang direndam selama 6 jam dan di fermentasi merupakan daging yang terbaik, namun tekstur daging yang dihasilkan tidak begitu cerah, oleh karena itu dalam penelitian ini diberikan perlakuan berupa suplementasi dengan Lactobacillus plantarum guna memperbaiki tekstur yang dihasilkan dan memperpanjang masa simpan dari daging itik yang digunakan

\section{MATERI DAN METODE PENELITIAN}

\section{Bahan-bahan Penelitian}

Bahan utama dari penelitian ini adalah daging itik bagian dada, sebanyak $10 \mathrm{~kg}$. itik yang digunakan adalah itik jawa yang sudah tidak produktif lagi. Saguer sebanyak 10 liter, saguer yang digunakan adalah saguer yang baru disadap dari pohon enau. Saguer difermentasi sesuai dengan perlakuan yang telah ditetapkan. Selain saguer juga digunakan garam sebagai perasa, bambu yang digunakan adalah bambu bulu sebanyak 36 potong dengan panjang setiap potongannya $30 \mathrm{~cm}$, serta kultur bakteri asam laktat L.Plantarum yang diperoleh dari Laboratorium PAU Pangan dan Gizi UGM.

Bahan untuk analisis mikroba yaitu media MRS broth, ekstrak tomat, aquadest steril, pepton water, PCA (Plate Count Agar), PGY, CaCO3, Yeast ekstrak, laurel sulfat tryptose broth, brillian green lactose bile broth,

$$
\text { Bahan-bahan kimia yang }
$$
digunakan untuk analisis kimia antara lain, buffer $\mathrm{pH} 4$ dan $\mathrm{pH} 7, \mathrm{NaOH}$, Phenophtalein, TCA, Asam Boraks, $\mathrm{K}_{2} \mathrm{CO}_{3}, \mathrm{H}_{2} \mathrm{SO}_{4}, \mathrm{Na}_{2} \mathrm{SO}_{4}, \mathrm{HgO}, \mathrm{Na}_{2} \mathrm{~S}_{2} \mathrm{O}_{3}$, HCL, Petcroleum eter, kertas warna whatman 41, M-thiobarbituric acid, $\mathrm{Pb}$ acetate, $\mathrm{Na}$ oxsalat, Ethanol, Hexan, $\mathrm{KOH}$, Methanol, Asam Heptadekanoat dan bahan kimia lainnya.

\section{Prosedur Penelitian}

\section{Fermentasi saguer}

Saguer yang sudah disiapkan dibersihkan dari kotoran-kotoran yang ada melalui penyaringan. Ditempatkan kedalam wadah yang telah disiapkan,wadah kemudian ditutup dengan plastik dan diinkubasi pada temperature ruang. Lamanya proses fermentasi sesuai dengan waktu yang telah ditetapkan yaitu 6 hari.

\section{Bambu}

Bambu yang digunakan adalah bambu dari jenis gombong dan telah dibersihkan bagian luarnya. Bambu dipotong-potong dengan ukuran $30 \mathrm{~cm}$ dan pemotongannya dilakukan pada tiap ruas yang ada, kemudian ditutup menggunakan plastik dan siap untuk digunakan. 


\section{Kultur L.Plantarum}

Kultur bakteri asam laktat (L.Plantarum FNCC 250) dalam ampul setelah dipotong ditambahkan $1 \mathrm{ml}$ aquadest steril dan ditumbuhkan dalam tabung reaksi yang berisi MRS broth $9 \mathrm{ml}$ yang diperkaya dengan ekstrak tomat $20 \%$ diinkubasi pada suhu $37^{\circ} \mathrm{C}$, selama 48 jam dan kemudian disimpan pada lemari pendingin.

\section{Kultur kerja.}

1 (satu) ose kultur diinkubasi kedalam 5 ml MRS broth yang telah diperkaya dengan ekstrak tomat $20 \%$ dan diinkubasi pada temperature $37^{0} \mathrm{C}$ selam 48 jam. Starter dibuat sebanyak $500 \mathrm{cc}$ yang ditempatkan dalam tabung reaksi dan disimpan pada temperature dingin. Penggunaan kultur kerja yang digunakan tidak disimpan dalam waktu yang lama.

\section{Daging Itik}

Itik yang tidak produktif dengan umur 2 tahun dipotong dan dikarkas, kemudian diambil karkas bagian dada dan dipotong menjadi 4 bagian, dicuci dan ditiriskan.

\section{Fermentasi dan Penyimpanan Daging Itik}

Daging itik yang telah bersih direndam menggunakan larutan saguer sesuai dengan lama fermentasi pada masing masing saguer. Perendaman dilakukan selama 30 menit. Karkas yang telah direndam tadi sebelum dimasukkan ke dalam tabung bambu ditaburi dengan sedikit garam dan disuplementasi dengan Lactobacillus plantarum dengan konsentrasi $(0 \%, 5 \%, 10 \%, 15 \%)$. Tabung bambu yang telah diisi dengan daging itik ditutup dengan plastik dan kemudian diinkubasi pada suhu ruang. Setelah proses fermentasi, dilakukan analisis secara mikrobiologis dan kimiawi dan kemudian disimpan pada temperature dingin $(0,4,8$, 12, 16 hari)

\section{Metode Penelitian}

Penelitian ini dilaksanakan melalui suatu percobaan menggunakan Rancangan Acak Lengkap Pola Faktorial (Steel., R.G. and Torrie, 1991) dengan 2 faktor (Main treatment) yaitu prosentase kultur Lactobacillus plantarum (0\%, 5\%, 10\%, 15\%) sebagai berikut : A1= Kultur $L$. plantarum $0 \%, \mathrm{~A} 2=$ Kultur L. plantarum 5\%, A3= Kultur L. plantarum 10\%, A4= Kultur L. plantarum 15\%. Sedangkan factor B (sub treatment) ialah lamanya penyimpanan daging pada temperature dingin. Sebagai berikut $: \mathrm{B} 1=$ Lama penyimpanan 0 hari, $\mathrm{B} 2=$ Lama penyimpanan 4 hari, B3 = Lama penyimpanan 8 hari, $\mathrm{B} 5=$ Lama penyimpanan 12 hari, B5 = Lama penyimpanan 16 hari.

Variabel yang diamati dalam penelitian 
ini adalah Kadar air (AOAC, 1990), pH, kadar asam asetat (Hadiwiyoto, 1992) dan Total bakteri Asam laktat ( Wibowo dan Ristanto,1988).

\section{HASIL DAN PEMBAHASAN}

\section{Analisis pH}

Pengaruh perendaman dalam kultur L. plantarum dan lama penyimpanan pada refrigerator yang dilakukan pada daging itik terhadap nilai $\mathrm{pH}$ dapat dilihat pada Tabel 1. Berdasarkan Tabel 1, terlihat bahwa perlakuan yang diberikan menyebabkan terjadinya perubahan terhadap $\mathrm{pH}$ yang dihasilkan. Pengaruh level L. plantarum yang berbeda yakni $0 \%, 5 \%, 10 \%, 15 \%$ menyebabkan $\mathrm{pH}$ mengalami penurunan sampai nilai $\mathrm{pH}$ yakni sebesar 4,92.

Begitu pula dengan pengaruh lama penyimpanan dalam refrigerator yang disimpan pada 0 hari , 4 hari, 8 hari dan 16 hari menyebabkan terjadinya perubahan
$\mathrm{pH}$ dari daging itik. Penurunan $\mathrm{pH}$ yang terjadi berkisar antara 6.19 sampai dengan 4.34 . Penurunan $\mathrm{pH}$ terendah terjadi pada penyimpanan hari ke-16 yakni sebesar 4.34 .

Nilai $\mathrm{pH}$ daging itik yang direndam dalam cairan L. plantarum pada level $15 \%$ dan disimpan selama 16 hari menghasilkan nilai $\mathrm{pH}$ yang sangat baik, dimana nilai $\mathrm{pH}$ daging yang difermentasikan menurut Rust (1987), dikatakan baik dengan kisaran $\mathrm{pH}$ 4.6-5.2.

Hasil analisis ragam menunjukkan bahwa perlakuan level L. plantarum yang di gunakan menyebabkan terjadinya penurunan $\mathrm{pH}$ sampai pada penggunaan $L$. plantarum level tertinggi yakni $15 \%$. Hasil pengujian menunjukkan bahwa perlakuan $0 \%$ berbeda nyata $(\mathrm{P}<0,05)$ dengan perlakuan $5 \%$, perlakuan level $5 \%$ tidak berbeda nyata dengan perlakuan level 10\% dan $15 \%$.

Tabel 1. Rataan pH Daging Itik Selama Penyimpanan Pada Refrigerator

\begin{tabular}{|c|c|c|c|c|c|}
\hline \multirow{2}{*}{$\begin{array}{c}\text { Lama Penyimpanan } \\
\text { (hari) }\end{array}$} & \multicolumn{4}{|c|}{ Level L. plantarum (\%) } & \multirow{2}{*}{ Rataan } \\
\hline & 0 & 5 & 10 & 15 & \\
\hline 0 & 6.13 & 6.08 & 6.08 & 6.50 & 6.19 \\
\hline 4 & 5.19 & 5.16 & 5.08 & 5.07 & 5.13 \\
\hline 8 & 5.15 & 4.84 & 4.99 & 4.60 & 4.80 \\
\hline 12 & 5.13 & 4.48 & 4.31 & 4.50 & 4.70 \\
\hline 16 & 5.07 & 4.20 & 4.09 & 4.01 & 4.34 \\
\hline Rataan & 5.33 & 4.95 & 4.91 & 4.92 & \\
\hline
\end{tabular}


Pengaruh lama penyimpanan menunjukkan bahwa perlakuan penyimpanan berbeda nyata $(\mathrm{P}<0,05)$ terhadap nilai $\mathrm{pH}$ daging itik yang dihasilkan. Penyimpanan 0 hari berbeda nyata lebih tinggi $(\mathrm{P}<0,05)$ nilai $\mathrm{pH}$ dibandingkan dengan lama penyimpanan 4 hari, demikian juga dengan penyimpanan 4 hari berbeda nyata lebih tinggi $(\mathrm{P}<0,05)$ dibandingkan dengan penyimpanan 12 hari. Sedangkan penyimpanan 12 hari tidak berbeda nyata dengan penyimpanan 16 hari.

Terjadinya penurunan $\mathrm{pH}$ dengan semakin tinggi penggunaan level $L$. plantarum disebabkan karena asam asetat yang ada pada saguer yang digunakan terdisosiasi ke dalam daging. Penyebab lain sehingga nilai $\mathrm{pH}$ mengalami penurunan yakni adanya peningkatan produksi asam laktat pada daging akibat perendaman dalam kultur L. plantarum pada level (0-15\%). Ini berarti semakin tinggi level L. plantarum meningkatkan aktivitas bakteri L. plantarum untuk menghasilkan asam laktat sehingga menyebabkan menurunnya nilai $\mathrm{pH}$ daging itik. Menurut Fardiaz (1992), bakteri asam laktat adalah bakteri yang menghasilkan asam laktat dan asam laktat yang dihasilkan akan menurunkan nilai $\mathrm{pH}$ dari lingkungan pertumbuhannya dan menimbulkan rasa asam.

\section{Kadar Air}

Pengaruh penggunaan $L$. plantarum dan lama penyimpanan terhadap kadar air daging itik dapat dilihat pada Tabel 2.

Dari Tabel 2, diketahui bahwa kadar air dari daging itik yang diberikan perlakuan perendaman dalam L. plantarum dengan level yakni $0 \%, 5 \%, 10 \%$ dan $15 \%$ menghasilkan kadar air berkisar 38.42\% $40.81 \%$.

Tabel 2. Pengaruh Penggunaan L. plantarum dan Lama Penyimpanan Terhadap Kadar Air Daging Itik

\begin{tabular}{cccccc}
\hline \multirow{2}{*}{$\begin{array}{c}\text { Lama Penyimpanan } \\
\text { (hari) }\end{array}$} & \multicolumn{4}{c}{ Level L. plantarum (\%) } & Rataan \\
\cline { 2 - 5 } & 0 & 5 & 10 & 15 & 39.98 \\
\hline 0 & 40.94 & 40.35 & 39.94 & 38.70 & 39.96 \\
8 & 40.88 & 40.63 & 39.85 & 38.48 & 39.81 \\
12 & 40.58 & 40.39 & 39.79 & 38.35 & 39.78 \\
16 & 40.92 & 40.27 & 39.71 & 38.32 & 39.56 \\
\hline Rataan & 40.74 & 40.08 & 39.19 & 38.24 & \\
\hline
\end{tabular}


Rataan presentase kadar air daging itik yang dihasilkan ini masuk dalam kisaran kualitas daging normal. Sebab menurut Winarno dan Fardiaz (1990) bahwa apabila daging mempunyai kadar air yang tidak terlalu tinggi kurang lebih $15-50 \%$ maka daging tersebut termasuk bahan setengah basah dan daging tersebut dapat tahan lama disimpan.

Berdasarkan hasil analisis ragam menunjukkan bahwa lama penyimpanan yang berbeda-beda pada daging itik yang diberikan perlakuan $L$. plantarum dengan level berbeda memberikan pengaruh yang tidak berbeda nyata $(\mathrm{P}<0.05)$ terhadap rataan kadar air daging itik yang dihasilkan.

Tidak adanya perbedaan nyata terhadap rataan kadar air yang dihasilkan disebabkan karena bakteri asam laktat yang digunakan mampu mengikat air yang ada dalam daging sehingga kadar air menjadi turun meskipun disimpan selama 16 hari.

\section{Kadar Asam Asetat}

Pengaruh lama penyimpanan dan perbedaan level L. plantarum yang digunakan terhadap kadar asam asetat daging itik dapat dilihat pada Tabel 3. Dari Tabel 3, terlihat bahwa perlakuan yang diberikan menyebabkan terjadinya perubahan terhadap kadar asam asetat yang dihasilkan. Pengaruh penggunaan L.plantarum yang berbeda yaitu $0 \%, 5 \%$, $10 \%$ dan $15 \%$ menyebabkan terjadinya perubahan kadar asam asetat yang diperoleh pada daging itik yaitu berkisar antara $10,71 \%$ sampai $15,15 \%$. Kadar asam asetat yang terendah diperoleh dari daging itik yang tidak direndam (0 jam).

Tabel 3. Pengaruh Penggunaan L. plantarum dan Lama Penyimpanan Terhadap Kadar Asam Asetat Daging Itik.

\begin{tabular}{|c|c|c|c|c|c|}
\hline \multirow{2}{*}{$\begin{array}{c}\text { Lama Penyimpanan } \\
\text { (hari) }\end{array}$} & \multicolumn{4}{|c|}{ Level L. plantarum (\%) } & \multirow{2}{*}{ Rataan } \\
\hline & 0 & 5 & 10 & 15 & \\
\hline 0 & 10 & 13 & 15 & 14 & 12,73 \\
\hline 4 & 11,4 & 14 & 15 & 16 & 13 \\
\hline 8 & 12,1 & 17 & 13,5 & 18 & 13,88 \\
\hline 12 & 10,2 & 13,8 & 14.5 & 17 & 14,1 \\
\hline 16 & 10,0 & 13,1 & 14,3 & 13,5 & 15,15 \\
\hline Rataan & 10,74 & 14,18 & 14,46 & 16.1 & \\
\hline
\end{tabular}


Daging yang tidak diberi perlakuan ini mendapatkan mendapatkan asam dari asam laktat yang diperoleh dari daging itu sendiri. Selanjutnya kadar asam asetat yang paling tinggi diperoleh pada daging itik yang diberikan $15 \%$ l. plantarum. Pengaruh perendaman karkas dalam saguer tidak menyebabkan terjadinya perubahan besar kadar asam asetat dibandingkan dengan pengaruh penggunaan L.plantarum.

Hasil analisis ragam menunjukkan bahwa perlakuan lama penyimpanan sampai 16 hari memberi pengaruh yang tidak berbeda nyata $(\mathrm{P}<0,05)$ terhadap kadar asam asetat dari daging itik. Ini berarti penyimpanan daging itik selam 16 hari tidak menyebabkan terjadinya perbedaan kadar asam asetat dari daging itik. Dari hasil analisis di atas menunjukkan bahwa kadar asam asetat yang dihasilkan pada penelitian ini hanya berasal dari asam laktat yang dihasilkan dari penggunaan perlakuan L.plantarum yang diberikan pada daging itik sedangkan kadar asam asetat pada perendaman karkas dalam saguer tidak memberikan pengaruh.

\section{Total Bakteri Asam Laktat}

Pengaruh lama penyimpanan dan perbedaan level L. plantarum yang digunakan terhadap total bakteri asam laktat daging itik dapat dilihat pada Tabel 4. Dari Tabel 4, dapat dilihat bahwa makin tinggi level L.plantarum menyebabkan terjadinya peningkatan jumlah nilai total bakteri asam laktat, sedangkan lama penyimpanan pada suhu rendah menyebabkan terjadinya peningkatan jumlah total bakteri asam laktat sampai penyimpanan 8 hari kemudian menurun pada penyimpanan 12 hari sampai pada penyimpanan 16 hari.

Tabel 4. Pengaruh Penggunaan L. plantarum dan Lama Penyimpanan Terhadap Total Bakteri Asam Laktat (Logx) yang Dihasilkan

\begin{tabular}{|c|c|c|c|c|c|}
\hline \multirow{2}{*}{$\begin{array}{c}\text { Lama Penyimpanan } \\
\text { (hari) }\end{array}$} & \multicolumn{4}{|c|}{ Level L. plantarum (\%) } & \multirow{2}{*}{ Rataan } \\
\hline & 0 & 5 & 10 & 15 & \\
\hline 0 & 1.30 & 6,77 & 6,83 & 6,92 & 5,45 \\
\hline 4 & 2,60 & 6,25 & 6,74 & 6,84 & 5,60 \\
\hline 8 & 2,84 & 7,04 & 6,47 & 6,71 & 5,76 \\
\hline 12 & 2.07 & 6,87 & 6,39 & 6,81 & 5,53 \\
\hline 16 & 1,00 & 5,65 & 5,70 & 5,64 & 4,49 \\
\hline Rataan & 1,96 & 6,52 & 6,43 & 6,60 & \\
\hline
\end{tabular}


Hasil analisis ragam menun jukkan bahwa penggunaan perlakuan pada daging itik berpengaruh sangat nyata $(\mathrm{P}<0,01)$ terhadap jumlah bakteri asam laktat. Hasil uji BNJ menunjukkan bahwa penambahan level L.plantarum sampai $15 \%$ yang digunakan pada daging itik memberikan pengaruh yang sangat nyata $(\mathrm{P}<0,01)$ terhadap jumlah bakteri asam laktat. Meningkatnya jumlah bakteri asam laktat pada daging itik menunjukkan adanya peningkatan jumlah dan aktifitas bakteri asam laktat untuk menghasilkan asam laktat, sebagai akibat dari penambahan level L.plantarum. Hal ini dapat terjadi karena penurunan $\mathrm{pH}$ atau terjadinya peningkatan kadar asam laktat dalam daging sehingga memungkinkan berkembangnya bakteri asam laktat. Seperti yang dinyatakan oleh Fardiaz (1992) bahwa bakteri asam laktat adalah kelompok bakteri yang menghasilkan sejumlah besar asam laktat yang akan menurunkan nilai $\mathrm{pH}$ dari lingkungan pertumbuhannya.

\section{KESIMPULAN}

Dari hasil penelitian yang dilakukan dapat disimpulkan bahwa penggunaan L. plantarum sampai $15 \%$ sebagai suplementasi pada daging itik fermentasi dan disimpan selama 16 hari menghasilkan daging itik yang masih baik dilihat dari nilai $\mathrm{pH}$, kadar air, kadar asam asetat dan total bakteri asam laktat

\section{DAFTAR PUSTAKA}

AOAC 1990. Association Of Official Analysis Chemical Official Methode Of Analysis $18^{\text {th }}$. Ed. Washington DC.

Bachman. M. R. 1981.

Technology Appropriate Of Food Preservation In Developing Countries dalam Development In Food Preservation Vol. I. Applied Science. Publisher. London P. 1-5.

Erwin Pandelaki. 2005. Pengaruh Penggunaan Tabung Bambu Terhadap Kualitas Daging Ayam. Skripsi. Fakultas Peternakan. UNSRAT.

Fardiaz, S. 1992. Petunjuk Laboratorium Analisis Mikrobiologi Pangan. Departemen Pendidikan dan Kebudayaan, Direktorat Jendral Pendidikan Tinggi. Pusat Antar Universitas Pangan dan Gizi. Bogor

Hadiwiyoto, S. 1983. Hasil-hasil Olahan Susu, Ikan, Daging dan Telur. Liberty Yogyakarta

Murtidjo. B. A. 1999. Mengelola Itik. Penerbit Kanisius. Jakarta.

Stell., R.G and Torrie. 1991. Prinsip dan Prosedur Statistik Suatu Pendekatan Biometrik. Terjemahan Ir. Bambang Soemantri. Gramedia Jakarta. 
Surono, I.S. 2000. Probiotik Susu Fermentasi Dan Kesehatan. Yayasan Perpustakaan.

Makanan dan Minuman Seluruh Indonesia. Tri Cipta Karya. Indonesia.

Winarno, F.G. dan Fardiaz. 1990. Pengantar Teknologi Hasil Pertanian. IPB. Bogor.

Wibowo dan Ristanto, 1988. Petunjuk Khusus Deteksi Mikroba Pangan. PAU Pangan dan Gizi. UGM. Yogyakarta 